\title{
The Carotenoid Pigment and Deoxyribonucleic Acid Base Ratio of a Rhizobium which Nodulates Lotononis bainesii Baker
}

\author{
By C. A GODFREY \\ Department of Soil Science and Plant Nutrition, Institute of Agriculture, \\ University of Western Australia, Nedlands, Western Australia 6009
}

(Accepted for publication Io April 1972)

INTRODUCTION

Pigmented mutants of Rhizobium have been described (Kleinkauf, I966; Gillberg, I969), but have never been demonstrated to nodulate a host or to be related serologically to the parent strain so that there is some doubt as to their identity. Isolates from Lotononis bainesii Baker remain the only known examples of pigmented rhizobia which are effective in nodulation (Norris, 1958). These strains have a strict host specificity, and only pigmented isolates effectively nodulate the host, $L$. bainesii. Strain CB360 (Norris, 1958) was not closely related to any other strain included in a survey of the genus Rhizobium and other genera of the family Rhizobiaceae (see strain 6I, Graham, I964). Immune diffusion antigenic analysis of selected strains of Rhizobium japonicum and of the cowpea group including strain $\mathrm{CB} 376$ from L. bainesii revealed no significant cross-reaction between this strain and others (Dudman, 197I).

Although these pigmented rhizobia are clearly unique, the nature of their pigment remains unreported and their relationship to other rhizobia is ill-defined. We investigated the possibility that their red pigment was a haemoprotein. In order to assess the genetic similarity of strain $\mathrm{CB} 360$ to other rhizobia, the mole \% of guanine+cytosine in its DNA was also determined.

\section{METHODS AND RESULTS}

Strain CB360 was cultured at $28^{\circ} \mathrm{C}$ on a yeast-mannitol medium (Godfrey \& Dilworth, I97I). Broth cultures were grown on a reciprocating shaker with adequate aeration to ensure pigment production and the bacteria harvested by centrifugation at $5000 \mathrm{~g}$ for $20 \mathrm{~min}$ after 3 to 5 days of growth. The bright red pigment remained intracellular and, in fact, extraction proved to be difficult. Disruption of the bacteria by grinding with alumina (Mcllwain, 1948) and extraction with $0^{\circ}$ I M-potassium phosphate buffer $(\mathrm{pH} 7 \cdot 0)$ followed by centrifugation at I0000 $\mathrm{g}$ for Io min yielded a light pink supernatant with a typical carotenoid visible absorption spectrum. Neither reduction with sodium dithionite nor addition of pyridine haemochromogen reagent (Paul, Theorell \& Åkeson, I953) altered the spectrum which established the non-haem nature of the pigment. Its visible spectrum and lack of $\mathrm{pH}$ dependence were clearly unlike that of the pyrrolic pigment, prodigiosin, produced by Serratia marcescens (Williams, Green \& Rappoport, I956).

Carotenoid pigments were, therefore, removed with acetone-methanol $(7: 3, v / v)$, acetone and then chloroform as described by Schmidt, Pfennig \& Liaaen-Jensen (1965). After drying the extract with anhydrous sodium sulphate and rotary evaporation of samples, the crude residues were dissolved in selected solvents and their spectra recorded on a Unicam SP-700 recording spectrophotometer. The extinction maxima above $450 \mathrm{~nm}$ wavelength 
Table I. Absorption maxima of crude extracts of Rhizobium sp., strain $\mathrm{CB} 360$, in selected solvents

Carotenoids with similar spectra are included for reference.

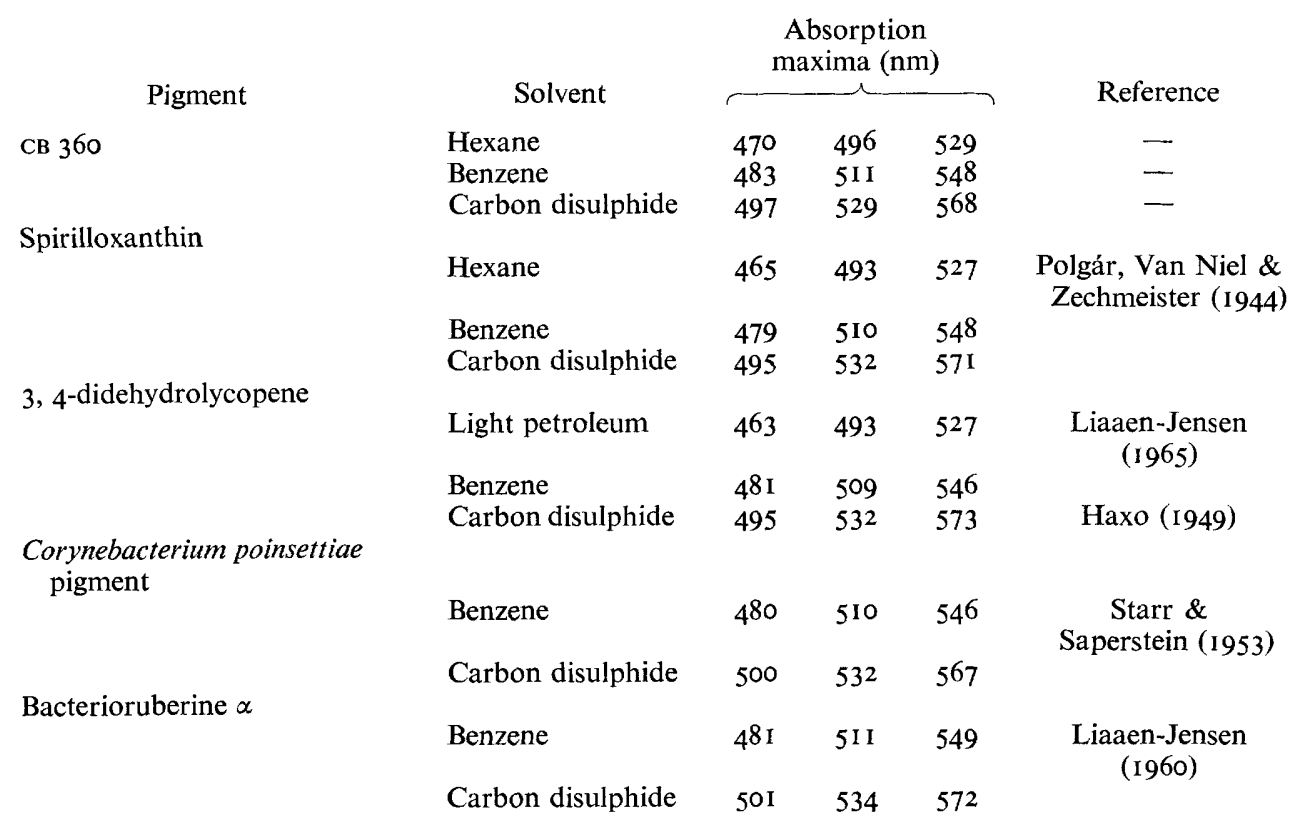

are shown in Table I together with data for carotenoids with a similar spectrum (Foppen, 1971).

Identification was not possible by this criterion alone. However, consideration of the taxonomic distribution of carotenoid pigments with similar spectra suggests that they are probably related to the $\mathrm{C}_{50}$ carotenoids of Corynebacterium poinsettiae and Halobacterium (Liaaen-Jensen, 1969). Spirilloxanthin and 3, 4-didehydrolycopene have so far been found only in photosynthetic bacteria and fungi respectively. Weeks (1971) has suggested that $\mathrm{C}_{50}$ carotenoids are unique to Gram-positive bacteria, although Halobacterium is an obvious exception. This Rhizobium, which is typical in being Gram-negative (Norris, 1958), would constitute another exception. However, as an exact identification of the pigment was irrelevant to our aims and would require extensive analytical studies, this aspect was pursued no further.

Nodules from Lotononis bainesii inoculated with strain Св360 and grown either in the field or in pots in the glass house (see Broughton \& Dilworth, 1971) were extracted for leghaemoglobin (Dilworth, 1969) which was found to be present. The bacterial pellets were not pigmented indicating that carotenoid synthesis was suppressed in the nodule. Isolations were made from nodules to check that the bacterial symbiont was truly the pigmented Rhizobium. The rhizobial colonies were all pigmented as observed by Norris (1958), although the viability of the nodule bacteria appeared to be low.

Determinations of the mole \% guanine + cytosine (GC) content of strain CB360 DNA were made using the method of Broughton, Dilworth \& Passmore (1972) which involves the hydrolysis of partially purified DNA preparations and quantitative measurement of the guanine and adenine released. This technique was developed in our laboratory and gave the 
expected values with a number of organisms including slow and fast growing rhizobia (Broughton et al. 1972). The mean value and standard deviation were $68 \cdot 9 \pm \mathrm{I} \cdot \mathrm{I} \%$ from the six determinations on strain Св360 $(68 \cdot 3,68 \cdot 4,7 \mathrm{I} \cdot 2,68 \cdot 1,67 \cdot 9,69 \cdot 2 \%)$, which is beyond the range (59 to $66 \%$ ) observed for other rhizobia (De Ley \& Rassel, 1965; Heberlein, De Ley \& Tijtgat, 1967). Perhaps this reflects the correlation between high $\% \mathrm{GC}$ content in bacteria and their pigmentation and exposure to sunlight ultraviolet proposed by Singer \& Ames (1970). Gillberg (1969) has reported a correlation between pigmentation and resistance to ultraviolet in non-infective mutants of Rhizobium, and $\mathrm{C}_{50}$ carotenoid-producing organisms possess DNA base ratios of over $70 \%$ with the exception of Halobacterium (60 to $69 \%$ ) according to Weeks (I97I).

The aberrant base ratio and other unique properties of the isolates from Lotononis bainesii compared to other rhizobia and the apparent linkage between pigmentation and infectivity (Norris, 1958) make them somewhat of an enigma within the genus. The ability to form nodules containing leghaemoglobins, however, supports their identity as rhizobia. Studies on the pigment are being undertaken.

This work was supported by a grant from the Rural Credits Development Fund of the Reserve Bank of Australia. The author thanks Miss J. Spackman for her capable assistance.

\section{REFERENCES}

Broughton, W. J. \& Dilworth, M. J. (1971). Control of leghaemoglobin synthesis in snake beans. Biochemical Journal 125, 1075-1080.

Broughton, W. J., Dilworth, M. J. \& Passmore, I. K. (1972). Base ratio determination using unpurified DNA. Analytical Biochemistry 46, I64-I72.

DE LEY, J. \& RASSEL, A. (I965). DNA base composition, flagellation and taxonomy of the genus Rhizobium. Journal of General Microbiology 4I, 85-9I.

DILWORTH, M. J. (1969). The plant as the genetic determinant of leghaemoglobin production in the legume root nodule. Biochimica et biophysica acta 184, 432-44I.

Dudman, W. F. (1971). Antigenic analysis of Rhizobium japonicum by immunodiffusion. Applied Microbiology 2r, 973-985.

Foppen, F. H. (197I). Tables for the identification of carotenoid pigments. Chromatographic Reviews 14, I33-I98.

GillberG, B. O. (1969). Pigmented variants of Rhizobium. Isolation, genetical constitution, heat- and u.v. resistance. Archiv für Mikrobiologie 69, 260-265.

GODFREY, C. A. \& DilWORTH, M. J. (1971). Haem biosynthesis from ${ }^{14} \mathrm{C}-\delta$-aminolaevulinic acid by laboratory grown and root nodule Rhizobium lupini. Journal of General Microbiology 69, 385-39o.

Graham, P. H. (1964). The application of computer techniques to the taxonomy of the root-nodule bacteria of legumes. Journal of General Microbiology 35, 5 I I-5I 7 .

Haxo, F. (1949). Studies on the carotenoid pigments of Neurospora. I. Composition of the pigment. Archives of Biochemistry 20, 400-42 I.

Heberlein, G. T., De Ley, J. \& Tijtgat, R. (1967). Deoxyribonucleic acid homology and taxonomy of Agrobacterium, Rhizobium and Chromobacterium. Journal of Bacteriology 94, I I6-I 24.

KLEINKaUf, H. (1966). Carotin und Carotinoidsynthese in Rhizobium lupini-Mutanten. Archiv für Mikrobiologie 53, I $54-158$.

LiAAEN-Jensen, S. (1960). Bacterial carotenoids. VI. A note on the constitution of Bacterioruberine $\alpha$. Acta chemica scandinavica 14, 950-952.

LiAAEN-JENSEN, S. (1965). On fungal carotenoids and the natural distribution of spirilloxanthin. Phytochemistry 4, 925-93I.

LiAAEN-JENSEN, S. (1969). Selected examples of structure determination of natural carotenoids. Pure and Applied Science 20, $42 \mathrm{I}-448$.

McIlwain, H. (1948). Preparation of cell-free bacterial extracts with powdered alumina. Journal of General Microbiology 2, 288-29I. 
NorRIs, D. O. (1958). A red strain of Rhizobium from Lotononis bainesii Baker. Australian Journal of Agricultural Research 9, 629-632.

Paul, K. G., Theorell, H. \& $\AA$ Keson, A. (I953). The molar light absorption of pyridine ferroprotoporphyrin (Pyridine haemochromogen). Acta chemica scandinavica 7, 1284-1287.

Polgár, A., VAN Niel, C. B. \& ZeChMeister, L. (1944). Studies on the pigments of the purple bacteria. II. A spectroscopic and stereochemical investigation of spirilloxanthin. Archives of Biochemistry 5, 243-264.

Schmidt, K., Pfennig, N. \& LiaAen-Jensen, S. (1965). Carotenoids of Thiorhodaceae. IV. The carotenoid composition of 25 pure isolates. Archiv für Mikrobiologie 52, I32-I46.

SiNGER, C. E. \& AMES, B. N. (1970). Sunlight ultraviolet and bacterial DNA base ratios. Science, New York I70, 822-826.

StARR, M. P. \& SAPERStein, S. (1953). Thiamine and the carotenoid pigments of Corynebacterium poinsettiae. Archives of Biochemistry 43, 157-168.

WeEks, O. B. (1971). Biosynthesis of $\mathrm{C}_{50}$ carotenoids. In Aspects of Terpenoid Chemistry and Biochemistry, pp. 29I-313. Edited by T. W. Goodwin. London: Academic Press.

Williams, R. P., GreEn, J. A. \& RAPPOPORT, D. A. (1956). Studies on pigmentation of Serratia marcescens. I. Spectral and paper chromatographic properties of prodigiosin. Journal of Bacteriology 71, I I 5- 20. 